\title{
Ulønnet og frivilligt arbejde
}

$\mathrm{L}$ angt de fleste undersøgelser, teorier og $\checkmark$ diskussioner indenfor arbejdslivsforskningen drejer sig enten implicit eller eksplicit om lønnet arbejde. Men hvad med alt det arbejde, man ikke får betaling for? Frivilligt arbejde, arbejde i lokalsamfundet, arbejdet som praktikant, ulønnet overarbejde, reproduktivt arbejde $\mathrm{mm}$. Denne form for arbejde er ikke bare ulønnet, men også usynligt og underbelyst i arbejdslivsforskningen. Dette temanummer har derfor til formål at bringe bidrag, der undersøger det ulønnede arbejde i dets mangfoldige former og organiseringer, samt dets individuelle og samfundsmæssige implikationer.

Meget ulønnet arbejde udføres i tæt tilknytning til, og nogle gange som erstatning for, regulært lønnet arbejde. Man kan argumentere for, at en senmoderne arbejdsetik, med høje krav til medarbejderens identifikation med og emotionelle engagement $i$ arbejdet, fører til en arbejdsindsats, der strækker sig langt ud over, hvad lønnen honorerer. Samtidig er flere brancher (fx. kulturområdet og dele af det akademiske arbejdsmarked) kendt for at have en institutionaliseret kultur for ubetalt overarbejde, ulønnede praktikforløb og lignende. Det ulønnede arbejde udføres i mange tilfælde af mennesker i prekære ansættelser (Gleerup, Nielsen, Olsén, $\&$ Warring, 2018). Mange er unge uden fast tilknytning til arbejdsmarkedet, der påtager sig dette gratis arbejde i håbet om at styrke deres $\mathrm{CV}$, 'at få et ben indenfor', og at øge deres fremtidige muligheder på arbejdsmarkedet (Wistreich \& Lystlund Matzen, 2016).
En anden fremtrædende version af ulønnet arbejde er frivilligt arbejde, dvs. ulønnet arbejde i relation til en sag, et formål eller en normativ orientering som den, der påtager sig arbejdet, ønsker at støtte/fremme. Frivilligt arbejde er udbredt i det danske foreningsliv, men vinder også i stigende grad indpas i offentlige velfærdsorganisationer (eks. ældrepleje og socialt arbejde), samt i tilknytning til socialøkonomiske virksomheder, hvor begreber som samskabelse og samproduktion bl.a. involverer brug af ulønnet arbejdskraft fra borgere, brugere og pårørende (jf. eksempelvis bidrag af Boje og Andersen i dette nummer). Denne type ulønnet arbejde er ofte båret af en ide om, at arbejdet giver noget immaterielt igen - eksempelvis glæden ved at hjælpe andre, gøre en god gerning, bidrage til en sag, styrke et lokalsamfund eller andet. Men det åbner også for nye interessante spørgsmål omkring eksempelvis latente værdi- og motivationskonflikter og praktiske positioner mellem ulønnede ildsjæle og det lønarbejdende personale i organisationerne. Endvidere peger udviklingen i velfærdsorganisationerne mod en stigende forventning til pårørende og familier om at løfte omsorgsopgaver og mod en re-privatisering af omsorgsopgaver, og dermed mod en re-aktualisering af diskussioner om særligt kvinders ulønnede reproduktive arbejde.

Klassiske feministiske teorier om reproduktivt arbejde og nyere omkring usynligt arbejde inviterer til at problematisere forholdet mellem lønnet og ulønnet arbejde (se fx Federici, 2012; Star \& Strauss, 1999). Ulønnet 
og frivilligt arbejde er således bl.a. interessant at beskæftige sig med i et tidsskrift for arbejdsliv, fordi det bidrager med nye vinkler til at diskutere arbejdsbegrebet. En måde er eksempelvis ved at problematisere, hvad vi overhovedet kan kategorisere som arbejde. I sin klassiske definition af følelsesarbejde sondrer Hochschild (1983) eksempelvis imellem betalt følelsesarbejde (emotional labour) og ubetalt følelsesarbejde (emotional work), selvom det konkrete arbejde med følelserne kan være det samme. Dette illustrerer, at sondringen mellem ubetalt og betalt arbejde kan være arbitrær (for nogle er det et arbejde at være fodboldtræner, ikke for andre), endvidere kan sondringen mellem frivillige/ubetalte og betalte arbejdsopgaver være inkonsistent henover det enkelte individs erhvervskarriere - og endda arbejdsdag. De specifikke opgaver, folk på et tidspunkt udfører som frivilligt arbejde, kan udvikle sig til konkret lønarbejde eller omvendt.

I dette temanummer udfoldes problemstillinger vedrørende ulønnet og frivilligt arbejde i tre peer-reviewede artikler, en kronik, to debatindlæg, samt en anmeldelse/essay.

I temanummerets første artikel "Medborger i frivilligt arbejde - velfoerdsproducent eller demokratiets vagthund" undersøger Thomas Boje det frivillige ulønnede arbejdes rolle i det danske velfærdssamfund. Boje argumenterer bl.a. for at civile organisationer overtager en del af statens sociale ansvar ved i sigende grad at overtage dele af deres opgaver, hvorved de civile organisationer kommer til at fungere som "en forlængelse af eller erstatning for staten". Således er ansvaret for "levering af velfærden" ifølge Boje "ikke længere alene en statslig opgave, men delt mellem velfærdsstat, marked og civilsamfund." Boje undersøger også udviklingen i den frivillige ulønnede arbejdsindsats i den civile sektor via en række eksisterende undersøgelser og opgørelser. Boje finder, at den civile sektor er karakteriseret af stor stabilitet, hvad angår omfanget af frivillighed, typen af frivilligt arbejde samt sektorens sammensætning. Til gengæld finder han ændringer i frivillighedens organisatoriske forankring samt den tid, danskerne bruger på frivilligt arbejde. Boje undersøger også hvorvidt der sker en professionalisering af nogle sektorer af frivilligt arbejde. Det gør han ved at undersøge omfanget af lønnet arbejdskraft set i forhold til den ulønnede indsats i organisationerne. Her finder han store forskelle mellem forskellige sektorer i det civile samfund.

Fra at undersøge omfanget og udviklingen i frivilligt arbejde i et strukturelt perspektiv, vender vi os i temanummerets anden artiklen mod en type ubetalt arbejde, som ganske givet ikke indfanges i Bojes undersøgelser af frivilligt arbejde som bidrag til velfærdssamfundet, nemlig unge 'selvvalgt arbejdsløse'. I sin bog om Prekariatet skriver Standing, at prekariatet både repræsenterer ufrivilligt marginaliserede, som er dæmoniseret af de eksisterende institutioner og 'helte', som gør oprør og forkaster disse institutionerog bruger dem. Det er denne dobbelthed som adresseres i Sabina Pultz' artikel om 'selvvalgt arbejdsløse'. Hun beskriver i sin artikel unge, som fastholder drømmen om, at arbejde skal være eksistentielt meningsfuldt og frembyde muligheder for kreativitet og selvudfoldelse, som et almindeligt lønarbejde ikke kan tilbyde. Disse unge bliver derfor 'selvvalgt arbejdsløse' og lever et liv, som er kompromisløst og på nogle måder frit- men også fyldt med skrøbelighed og ambivalens. På den ene side lever de af den danske 'flexicurity-model' og et a-kassesystem, som gør det muligt at leve relativt godt i en periode uden at have et lønarbejde. På den anden side er de også kritiske over for selvsamme system og markedskapitalismen. Pultz tager afsæt i britiske governmentality sociologer, der har analyseret fremvæksten af neo-liberalisme, new public management og 'enterprise culture' siden Thatcher kom 
til magten i 1980'erne. Disse sociologer har analyseret bestræbelserne på at få borgerne til at opfatte arbejdet som en helt central del af deres selvrealiseringsprojekt og at opføre sig som iværksættere fremfor 'passive modtagere af understøttelse'. Det afspejler sig i sproglige forskydninger, hvor 'arbejdsløse' bliver til 'jobsøgende'. Nogle af de samme træk kan Pultz identificere blandt de 'selvvalgt arbejdsløse' i dagens Danmark. Deres forhold til systemet er dog tvetydigt. På den ene side har de næsten overtrumfet systemlogikken og 'enterprise-idealerne' i dén forstand, at de mener, at systemet er for 'gammeldags og trægt': I deres selvforståelse er de hverken arbejdsløse eller 'jobsøgende' - de er 'jobskabende' og dermed kreative i en forstand, som systemets kategorier ikke rummer plads til. Og de lever op til iværksætteridealerne: de arbejder hårdt og dedikeret i projekter, som de brænder for. De abonnerer også på iværksætterfortællingen om, at det er op til individet selv at 'netværke' og at skabe sig sit eget arbejde. Men deres praksis er ulovlig og kalder på individuel skjult tilpasning snarere end kollektiv mobilisering. Og deres identitetsarbejde er tvetydigt og afhænger af, at de kan definere sig i forhold til nogle andre og noget 'udenfor'. Det gælder både 'systemet', som nævnt ovenfor, og det gælder 'de andre arbejdsløse'. De kommer således til at reproducere forestillingerne om disse 'andre arbejdsløse' som dovne og inkompetente.

Fra de unge, der befinder sig i begyndelsen af (løn)arbejdslivet, flytter vi i den tredje artikel blikket til livets afsluttende fase i Karen Sangild Stølen, Michael Hviid Jacobsen og Mette Raunkiærs analyse af frivillige vågeres ulønnede arbejde hos døende. Stølen mfl. analyserer med afsæt i fænomenologisk omsorgsfilosofi og et symbolsk interaktionistisk 'boundary work' perspektiv, hvad der kendetegner frivillige vågeres arbejde, når de sidder hos døende, samt hvilke udfordringer og muligheder der knytter sig til grænser mellem frivilligt og professionelt arbejde hos døende i palliative plejeforløb. Arbejdet med omsorg for døende har, i vores velfærdsstatslige kontekst, historisk bevæget sig fra en placering som del af den private sfæres ulønnede reproduktive arbejde, til, som forfatterne beskriver, i det senmoderne samfund at være blevet "noget, vi forventer, at institutioner og professionelle tager sig af". Artiklen beskæftiger sig dog med en interessant modbevægelse, hvor institutioner og professionelle opleves, og oplever sig selv, som utilstrækkelige i deres varetagelse af 'dødsarbejdet', hvorfor ulønnede frivillige vågere i stigende grad involveres i dette. Forfatterne illustrerer, hvordan frivillige vågere kan bidrage med et særligt sansende og stedfortrædende omsorgsarbejde, der muliggøres af deres uafhængighed af de snærende og accelererede styringsmæssige rammer i velfærdsstatens institutioner. De ulønnede omsorgsarbejdere besidder nemlig en særlig ressource, som det lønnede personale i stadigt mindre grad gør: tiden til at være nærværende hos den døende. Artiklen viser hvordan både frivillige og professionelle i deres løbende interaktioner omkring palliative forløb aktivt markerer og opretholder grænser mellem det lønnede og det ulønnede arbejde. Samtidig, viser den dog også hvordan disse formelle grænser i praksis overskrides og udvides i det situationsspecifikke omsorgsarbejde for både de døende og deres pårørende. Artiklen viser således vigtige kvaliteter ved det frivillige omsorgsarbejde, men stiller samtidig et kritisk spørgsmålstegn ved betingelserne for udfoldelse af meningsfuldt, etisk og nærværende lønnet omsorgsarbejde i velfærdsstatens institutioner.

I kronikken "Hybride civilsamfundsorganisationer under forandring: neoliberale praksisser, marked og civile rettigheder" undersøger Linda Lundgaard Andersen nogle implikationer ved at civilsamfundet og frivillige (også) indgår som strategiske samarbejdspartnere i løsninger af offentlige opgaver. Andersen argumen- 
terer for, at der i disse partnerskaber udvikles en særlig "hybrid praksis", hvor det ulønnede og lønnede eksisterer side om side. Det betyder, at civilsamfundsorganisationer baseret på frivilligt arbejde gradvist er blevet integreret i større dele af den offentlige velfærdsservice-profil. Andersen problematiserer blandt andet, at det frivillige sociale arbejde i denne sammenhæng kommer til at blive defineret og styret af markedsforhold. Frivilligt socialt arbejde indlejres således i en offentlig-civil kontraktkultur samt en markedsretorik, der omskriver frivillige til serviceydere.

I temanummerets to debatindlæg behandles også samarbejde, eller med et af tidens populære termer - samskabelse - mellem offentlige og private aktører. Her har vi bedt henholdsvis Kommunernes Landsforening (KL) (ved Michael Ziegler og Thomas Adelskov) og FOA (ved Mona Strib) om at forholde sig til, hvilke muligheder og begrænsninger, der knytter sig til brugen af frivilligt arbejde i velfærdsstaten. Samt hvilke udfordringer brugen af frivillige rejser ift. relationer, samarbejde og opgavefordeling mellem frivillige og lønnede medarbejdere. Fra KLs side lægges der ikke overraskende stor vægt på potentialerne $\mathrm{i}$ at involvere og samarbejde med frivillige og civilsamfundsorganisationer om at skabe velfærd. Nøgleord i denne fremstilling er 'nye fællesskaber', 'sammenhængskraft', 'netværk' og 'styrkelse af borgernes selvstændighed'. Fra FOAs side lægges der også vægt på potentialerne ved involvering af frivillige, men heller ikke overraskende peges der også på, at brugen af frivillige spiller sammen med nedskæringer i velfærdsorganisationerne, og på at frivilligt arbejde i visse tilfælde erstatter professionelt lønnet arbejde. Dette kan true den faglige kvalitet, og endvidere er det ifølge FOA "helt uigennemtaenkt hvilke konsekvenser det i fremtiden får for vores universelle velfoerd.". En vis enighed mellem arbejdsgivere og ar- bejdstagere kan dog spores i spørgsmålet om grænsesætninger mellem det lønnede og det ulønnede velfærdsarbejde. Både KL og FOA fremhæver vigtigheden af dialog om grænser og betoner et behov for klare rammer, aftaler, strukturer og rollefordelinger, når frivillige involveres. Disse strategiers slagkraftighed kan dog siges at blive draget i tvivl af flere af de andre bidrag i dette nummer, der netop betoner hybridisering, udvidelse og overskridelse af grænser mellem lønnet og ulønnet arbejde i hverdagens situationsbestemte praksisser.

Sidst, men ikke mindst, bringer vi en, med anmelderen Lise Lotte Hansens egne ord, 'aktivistisk anmeldelse' af Cinzia Arruzza, Tithi Bhattacharya og Nancy Frasers nye feministiske manifest: Feminism for the 99\%. Her sættes det ulønnede reproduktive arbejde på dagsordenen på ny, og modsætningsforholdet mellem 'profit making' (produktion) og 'people making' (social reproduktion) i nutidens neoliberale og finansielle kapitalisme fremhæves. Neoliberalismen har ifølge forfatterne skabt en omsorgskrise, idet den fordrer, at lønarbejdet optager stadigt mere tid og flere kræfter, mens den sociale reproduktion usynliggøres og forsømmes, når der samtidig skæres ned på sociale ydelser og services. Denne omsorgskrise udpeges som afsæt for tidens vigtigste feministiske kampe. Vores aktivistiske anmelder kan følge analysen et stykke af vejen, men peger også på væsentlige punkter, hvor den kommer til kort udenfor en nordamerikansk kontekst, og efterspørger endvidere mere mobiliserende kampgejst fra en bog, der betegner sig selv som et kampskrift.

God loeselyst!

Agnete Meldgaard Hansen, Morten Kyed \& Jakob Krause-Jensen 


\section{REFERENCER}

Federici, S. (2012). Revolution at Point Zero - Housework, Reproduction and Feminist Struggle. Oakland/Brooklyn: PM Press/Common Notions/Autonomedia.

Gleerup, J., Nielsen, B. S., Olsén, P. \& Warring, N. (2018). Prekarisering og akademisk arbejde. Tidsskrift for Arbejdsliv, 20(1), 9-29. https:// doi.org/10.7146/tfa.v20i1.108195.

Hochschild, A. R. (1983). The managed heart: Commercialization of human feeling. Berkeley. University of California Press.
Star, S. L. \& Strauss, A. (1999). Layers of Silence, Arenas of Voice: The Ecology of Visible and Invisible Work. Computer Supported Cooperative Work (CSCW), 8(1-2), 9-30. https://doi. org/10.1023/A:1008651105359

Wistreich, M. \& Lystlund Matzen, P. (2016). Dynamisk, kreativ, prekær - Noter fra det kulturelle prekariat. Retrieved November 5, 2019, from Friktion - Magasin for køn, krop og kultur website: https://friktionmagasin.dk/ dynamisk-kreativ-prekær-noter-fra-det-kulturelle-prekariat-e0495b544a29 